ORIGINAL ARTICLE

Received:2020/02/20

Accepted:2021/03/16

\title{
Causes and Consequences of Early marriage and the Occurrence of Child Marriage in Female Students in Yazd Province: Grounded Theory Study
}

\author{
Hassan Zareei Mahmoodabadi (Ph.D.) ${ }^{1}$, Fateme Zarei(M.A) ${ }^{2}$
}

1.Corresponding Author: Associate professor, department of Psychology, Yazd university. Yazd. Iran.

Email :zareei_h@yahoo.com_Tel:3531233570

2.M.A in Social worker, Educational System, Yazd, Iran.

\begin{abstract}
Introduction: Among the threats that change the family structure are early marriage and the phenomenon of child marriage. The World Health Organization considers early marriage as the marriage under the age of eighteen. Due to the importance of this issue, this study aimed to examine the causes and consequences of early marriage and the occurrence of child marriage in female students of Yazd province.

Method: This qualitative study was conducted based on the grounded theory. The research environment included all divorced female high school students in the academic year of 209-2010 in Yazd province. Of the participants and based on theoretical, targeted, and snowball sampling, in-depth semi-structural interviews were conducted on them and until the theoretical saturation was reached, 11 people were finally selected.

Result: The data were analyzed using Strauss and Corbin method with three steps of open, axial, and selective coding. Finally, from open coding 550 initial concepts, from axial coding 27 categories, and finally 8 main categories were extracted. The main categories included lack of communication, irresponsibility, lack of marital intimacy, lack of socio-moral maturity, psychological turmoil, risks and consequences of divorce, academic challenges and interpersonal problems.

Conclusion: The results showed that early marriage has many disadvantages, including divorce. Communication problems were at the top of students' problems at the time of marriage. This lack of communication leads to problems, such as marital intimacy, interference of others, educational problems, and sometimes infidelity.
\end{abstract}

Keywords: Early Marriage, Child Marriage, Students, Grounded Theory Conflict of interest: The authors declared that there is no Conflict interest.

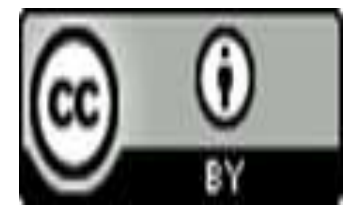

This Paper Should be Cited as:

Author: Hassan Zareei Mahmoodabadi, Fateme Zarei . Causes and Consequences of Early marriage and the Occurrence of Child Marriage in Female Students .............Tolooebehdasht Journal.2021;20(3):12-27.[Persian] 
علل و بيامدهاى ازدواج زودهنغام و وقوع كودكى همسرى در دانش آموزان دختر استان يزد( طلاق دانش آموزى): مطالعه داده بنياد

نويسند كان: حسن زارعى محمود آبادى'، فاطمه زارعى

ا انويسنده مسئول. دانشيار گروه روان شناسى و مشاوره، دانشگاه يزد، يزد، ايران.

Email: zareei_h@yahoo.com

تلفن تماس : :

enting \&gith r. كارشناس ارشد مدد كارى اجتماعى، آموزش و يرورش ميبد، يزد، ايران.

جكيله

مقلمه: از جمله آسيبهايى كه كانون خانواده را دستخوش تغيير قرار مىدهد؛ ازدواج زودهنگام و يديده كودكك همسرى است. سازمان جهانى بهداشت، ازدواج زير هجده سال را ازدواج زودهنگام تلقى مى كند. با توجه به اهميت اين موضوع، بثزوهش حاضر با هدف بررسى علل و بيامدهاى ازدواج زودهنگام و وقوع كودك همسرى در دانش آموزان دختر مطلقه استان يزد انجام شد. روش بروسى: اين يُؤه كيفى و راهبرد آن نظريه داده بنياد بود. محيط يُوهش شامل تمام دانش آموزان دختر مطلقه مقطع متوسطه دوم در سال تحصيلى 99- ^هسا استان يزد بود. از بين شركت كنند كان و بر مبناى نمونه گيرى نظرى، هدفمند و كلوله برفى، مصاحبه نيمه ساختارى عميق بر روى آنها اجرا كرديد و تا رسيدن به اشباع نظرى تعداد ال انفر در نهايت انتخاب شدند. يافته ها: دادهها با استفاده از روش اشترواس و كوربين و با سه مرحله كد كذارى باز، محورى و كرينشى يا انتخابى، تحليل شدند. از نتايج كدگذارى باز •لها نشان اوليه و در مرحله محورى لrمقوله و در نهايت مقوله اصلى شامل: نقصان ارتباطى، عدم مسئوليت يذيرى، عدم صميميت زناشويى، عدم بلوغ اجتماعى اخلاقى، آشفتگى روانى، مخاطرات و بيامدهاى طلاق، جالش تحصيلى و مشكلات بين فردى استخراج

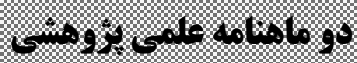

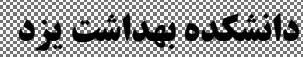
inim $\int$ pger o, lat

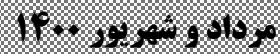
AV: Imino of

شدند. نتيجه كيرى: نتايج نشان داد ازدواج زودهنگام آسيب هاى زيادى ازجمله طلاق بدنبال دارد. مشكل

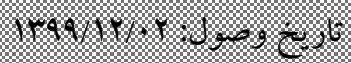

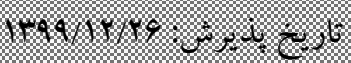
ارتباطى در راس مشكلات دانش آموزان در زمان تاهل بود. اين بى مهارتى ارتباطى، مشكلاتى از قبيل عدم صميمت زناشويى، دخالت هاى اطر افيان، مشكلات تحصيلى و كاهى خيانت را به دنبال دارد. وازههاى كليدى: ازدواج زودهنگام، كودكى همسرى، طلاق دانش آموزى، ازدواج بهنگام، نظريه داده بنياد 
افراد از ازدواج فقط حمايت شدن است، به طورى كه به دنبال

يكك جادمى يككطرفه در ازدواج هستند(^). يكى از يِيامدهاى منفى ازدواج زودهنگام طلاق است (9). منظور از طلاق دانش آموزى همان طلاق در سنين زير \1 سالكى است كه سال هاى تحصيل افراد در مدرسه را در بر مى گيرد. بنابر تعريف سازمان حمايت از كودكان سازمان ملل متحد به ازدواج در سنين پايين تر از ^\ سال همان (UNICEF) ازدواج كودكان يا كودكى همسرى اطلاق مى شود (•(1). در واقع ازدواج هاى زود هنگام در سنينى اتفاق مى افتد كه از آن ها به عنوان سنين مدرسه يا سن تحصيل ياد مى شود (11). براساس آخرين آمار و اطلاعات موجود از طريق دادههاى سازمان ثبت و احوال كشور در سال Vqrاحدود هFqه هزار و 191 مورد ازدواج و هم جنين ال هزار و •هو مورد طلاق در ايران ثبت شده است. هم جنين در سال VIr بالاترين ميزان طلاق مربوط به زنان سن ها تا 19 سال و مردان •r FF سال كال

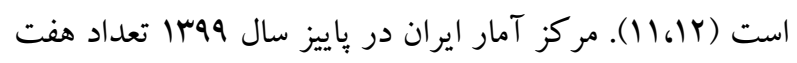
هزار و سيصد و هفده ازدواج دختر بجه ·ا تا F| سال رادر

$$
\text { كشور ثبت نموده است (r) - كا). }
$$

تحقيقات در خصوص ازدواج زود هنگام كمتر به سمت بيامدها و آسيب هاى اين نوع ازدواج رفته است. بيامد و آسيب هنين ازدواجى طلاق زودهنگام است. با اين وجود يزوهشهاى اندكى هم به طلاق در سنين پايين بالاخص، طلاق در دوران دانش آموزى يرداختهاست. به نظر مىرسد درصد بالايى از افرادى كه در اين سنين ازدواج مى كنند به دلايل مختلف دجار

$$
\text { اختلافات زناشويى مىشوند. }
$$

مقدمه دانش آموزان نوجوان با جالش هاى بسيار زيادى از جمله تحصسيل، بلوغ و ازدواج موا جه هستند. ازدواج زود هنكام (Child يا بِيده كودكك همسرى (Early Marriage) بarriage) مسايل فرهنخى و سنتى حاكم بر جامعه اتفاق مى افتد (Y) (Y). اين نوع ازدواج در كشورهاى درحال توسعه هم ديده مى شود (Y). افرادى كه در نوجوانى ازدواج مى كنند به لحاظ مالى، مديريت زندگى و مهارت هاى ارتباطى (Communication Skills) از سطح بايين ترى برخوردارند و هم جنين آمادكى كمترى براى يذيرش نقش مادرى و همسرى دارند (r). دلايل ازدواج زود هنگام مى تواند ناشى از هيجانات و عشق هاى دوره نوجوانى، اجبار خانواده ها، موقعيت اقتصادى و اجتماعى پبايين خانواده

ازدواج زودهنگام معمولا آسيب هاى فردى و اجتماعى، بيمارى هاى جسمانى و مشكلات روانى، نارضايتى از زندگى زناشويى به همر اه دارد كه در نهايت مى تواند به طلاق منجر شوند (ه). افر ادى كه در سن هايين ازدواج مى كنند شايد به قدر كافى بالغ نشدهاند كه نيازهاى عاطفى خود را بر آورده كنند و ارزشهاى اين افراد نيز در طى زمان و با بزرك شدن آن ها تغيير مى كند و در نتيجه بِ از مدتى منجر به ناساز گارى و ناهماهنكى بين اين زوجين مىشود (9). از طرفى بسيارى از اختلافات در روابط زناشويى به دليل عدم تناسب زوجين از نظر ويزگى هاى فردى و فرهنگى از جمله عدم تناسب سن است (V). افر ادى كه به بلوغ عاطفى نرسيدهاند تنها در زندگى به خود فكر مى كنند هدف اين 
هستند، به همين علت است كه اولين و بارز ترين ييامد احتمالى ازدواج در سنين بايين تداخل نقش همسرى و يا حتى مادرى با نقش دانش آموزى مى باشد كه در بيشتر موارد دانش آموزان(مخصوصا دختران) مجبور به ترك تحصيل مى شوند و يا در صورت ادامه تحصيل با افت تحصيلى مواجه مى شوند. ازدواج زود هنگام تاثيرات جسمى، روانى و حتى اقتصادى زيادى براى دختران دارد. يُزوهش ها نشان مى دهد كه دخترانى كه در سن پيايين ازدواج مى كنند، قدرت تصميم گيرى كمى در مسائل زناشويى دارند هم جِنين به نظر مى رسد، ازدواج زود هنگام دانش آموزان دختر مى تواند براى ساير هم كلاسى ها

ييامد هاى اجتماعى زيادى داشته باشد(r). اهميت و ضرورت بررسى مساله ازدواج زودهنگام و وقوع كودك همسرى بر هيج كس يوشيده نيست. دانش آموزى كه مى بايست بيشترين وقت خود راصرف تحصيل نمايد، آكاهانه يا ناآكاهانه در مسيرى قرار مى گيرد كه براى آن هيج آموزشى از قبل دريافت نكرده است. از بيامدهاى منفى خنين ازدواجى همان طور كه قبل اشاره شد طلاق است. طلاق دانش آموزى و يميامدهاى آن مى تواند بر دانش آموز، ساختار خانواده و تربيت نسل آينده اثربخذارد. تاكنون يزوهش هاى اندكى در اين حوزه انجام گرفته است. لذا اين بُوهش بدنبال كشف علل و بيامدهاى ازدواج زودهنگام و وقوع كودك همسرى در دانش آموزان دختر استان يزد است.

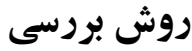

يُزوهش حاضريكك مطالعه كيفى و راهبرد آن نظريه داده بنياد يا مبتى بر داده بود. جامعه آمارى يُزوهش شامل تمام دانش آموزان دختر مطلقه در سال تحصيلى 99-194ا در مدارس متوسطه دوم
در :ثزوهش جرى و همكاران(|f) تحت عنوان ازدواج زود هنگام و موانع آن در ميان زنان سوريه و لبنان به اين نتيجه رسيدند كه ازدواج زودهنكام و باردارى زنان در سنين پايين مى تواند بيامد هاى منفى داشته باشد و هم جنين به ترتيب طلاق زود هنكام و عدم رعايت بهداشت بارورى را افزايش مى دهد. در بزوهش حيدرى و همكاران (1) تحت عنوان كشف عوامل موثر بر طلاق در ازدواج هاى زودهنگام نشان داد كه سن بايين در هنكام ازدواج يكى از دلايل اصلى طلاق است. مخصوصا زمانى كه ازدواج اجبارى يا از روى اجبار يا مصلحت انديشى

در يثزوهش مقدادى و جواديور (19)كه درباره تأثير ازدواج زودهنگام بر تركت تحصيل زنان جوان در ايران كه با رويكرد جند سطحى بر روى زنان 10 تا 19 سال كشور انجام داده است، عنوان مى كند كه هها٪ افراد متأهلى كه ترك تحصيل كرده اند ازدواج را علت ترك تحصيل خود دانسته اند. بُزوهش جواديان و همكاران(IV) نشان داد افرادى كه زود ازدواج مى كنند مهارت هاى لازم براى زندگى مشترك را ندارند و نمى تو انند صميميت لازم را برقرار كنند و زندگى زناشويى آن ها بيشتر دستخوش بى ثباتى مى شود. يُزوهش افتخارى (1) نشان داد ازدواج بهنكام باعث از بين رفتن شكاف نسل ها شده و فاصله سنى فرزندان با والدين راكم ميكند و باعث مى شود با فرزند آورى جوانان، قشر جوان جامعه درصد بيشترى از جمعيت را به خود اختصاص دهد. از آنجايى كه افراد به عنوان دانش آموز ملزم به ايفاى وظايفى همجون حضور به موقع در مدرسه و كلاس درس، انجام تكاليف، شركت در امتحانات و كسب حداقل نمره قبولى 
براى رعايت معيار قابليت اطمينان نيز مصاحبه هاى ضبط شده، متون نسخه بردارى شده از مصاحبه ها، فهرست مصاحبه شوندكان، يادداشتهاى يُزوهشخر و فرآيند تحليل داده ها ذخيره شد. هم جنين براى دستيابى به معيار تاييد يذيرى در اين يُزوهش نتايج تحليل ها و نظريه به دست آمده از طريق تبادل نظر با متخصصين خانواده و ازدواج بررسى شد. اين بثوهش زير نظر مدير كل محترم آموزش و يرورش استان يزد انجام گرفت. اين يزوهش مجوز اجرا از آموزش و يرورش در تاريخ مهرماه 19 ارارا دارد. اطمينان به محرمانه باقى ماندن اطلاعات و عدم استفاده از نام اصلى شركت كنند كان در مقاله، و همجنين انصراف از يزوهش در تمامى مراحل تحقيق به مشاركت

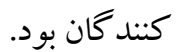

اين يُزوهش در كميته اخلاق دانشكاه يزد با شناسه IR.YAZD.RES.1400.48

يافته ها ميانگين و انحراف استاندارد سن دانش آموزان دختر در اين

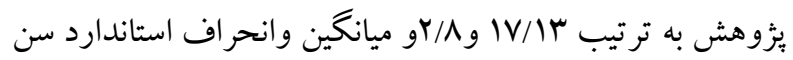
همسرانشان به ترتيب YF/YV و F/9 بود. هم جنين ميانگين مدت زمان ازدواج 9 ماه و انحراف استاندارد ^/· بود. مشخصات مشاركت كنندگان آمده است(جدول ().بعد از اجراى كد كذارى حدود •هه كد اوليه به دست آمد كه در قالب TV مقوله فرعى و ^مقوله اصلى دسته بندى شد مقوله هاى اصلى عبارتند از: نقصان هاى ارتباطى، عدم مسئوليت يذيرى، عدم بلوغ اجتماعى اخلاقى، عدم صميميت زناشويى، آشفتگى روانى، مخاطرات طلاق، جالش تحصيلى، مشكلات بين فردى، در ادامه هر كدام از مقوله ها به تفصيل بيان شده است(جدول Y).
استان يزد بود. برخى شرايط ورود عبارت بودند از 1. مشاركت كنده، دانش آموز باشد ז. دانش آموز حتما طلاق گرفته باشد r.دانش آموز با ميل خودش در اين يُوهش شركت كند و برخى شرايط خروج ا. سابقه بيمارى اعصاب و روان r. دانش آهوز در شرف طلاق باشد. از بين شركت كنند كان و بر مبناى نمونه گيرى نظرى، هدفمند و گلوله برفى از بين شهرهاى يزد، ميبد و اردكان، مصاحبه نيمه ساختارى عميق بر روى آنها اجرا گرديد و تا رسيدن به اشباع نظرى تعداد 1ل نفر در نهايت انتخاب شدند. مصاحبهها با توجه به كيفيت باسخ مشاركت كنند كان و علاقه آن ها به ادامه مصاحبه بين ا تا ه/1/ ساعت طول كشيد. بعد از انجام مصاحبه، ابتدا جلسات ضبط شده به شكل وازه به وازه و دقيق تايب گرديد؛ سبس با گُش دادن جندباره به فايل هاى صوتى و اطمينان از صحت مطالب يادداشت

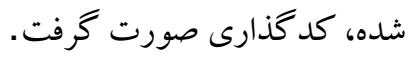
براى تحليل اطلاعات به دست آمده در روش داده بنياد، روش هاى گوناگونى وجود دارد كه يكى از بركاربردترين آن ها روش نظام مند و با استفاده از نرم افزار مكس كيو دا است(19). در اين روش براى تجزيه وتحليل داده ها، از سه مرحله كدگذارى باز،كدگذارى محورى و كدگذارى انتخابى و در نهايت ارائه يكك بارادايم منطقى از نظريه در حال رشد استفاده كرديد(19) در إزوهش حاضر براى اعتبار پِيرى ازمشاركت كنندكان خواسته شد تا يافتههاى كلى مطالعه را ارزيابى كرده و در مورد صحت آن نظر دهند. براى ييشخيرى از سو گيرىهاى احتمالى يُزوهشخر در جريان يُزوهش از فن بحث و تبادل نظر با همتايانى كه سرو كارى با بثزوهش حاضر نداشتند استفاده گرديد. 
جدول ا: ويز گى هاى جمعيت شناختى دانش آموزان

\begin{tabular}{|c|c|c|c|c|c|}
\hline سن همسر & رشته & مدات & بايه & سن دختر & رديف \\
\hline YF & سفالكرى & II 11 & يازدهم & 19 & 1 \\
\hline rی & حسابدارى & ب سال & دهم & 19 & r \\
\hline$r$. & انسانى & اهنته & دهم & 19 & $r$ \\
\hline 19 & كامبيوتر & ا سال & يازدهم & iv & F \\
\hline rI & سراميكك & 9 & يازدهم & 19 & $\Delta$ \\
\hline rq & مديريت & D Dاه & يازدهم & 11 & 9 \\
\hline$r \cdot$ & انسانى & r ماه & يازدهم & 11 & v \\
\hline ro & كامييوتر & r هفته & دهم & 10 & $\wedge$ \\
\hline$r$. & مديريت & Y كفته & يازدهم & iv & 9 \\
\hline rq & مديريت & هاه & يازدهم & IV/D & 1. \\
\hline rr & - & 1/V سال & هشتم & 19 & 11 \\
\hline
\end{tabular}

جدول ז: استخراج مقوله هاى اصلى و فرعى حاصل از ازدواج زودهنگام در دانش آموزان

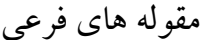

عدم آشنايى مرد با مهارت هاى ارتباطى -عدم تمايل به مشاوره- اعمال محدوديت

هاى ارتباطى-نقش شبكه هاى مجازى - ارتباطات خارج از خارجوب لهاب

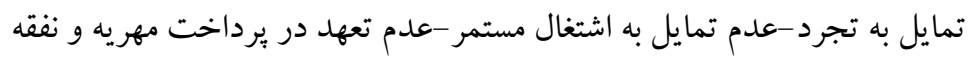

$$
\text { بع علاقه گَى -بى احساسى }
$$

-عدم استقلال فكرى و اقتصادى-سكوت نابجاى خانواده-تصور اشتباه از تاهل -

$$
\text { عدم بلوغ جسمى و اجتماعى دختر }
$$

-تغيير خلق و رفتار پس از تاهل-ضرب و شتم غير عادى زن-مصرف مخفيانه

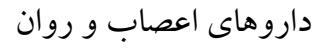

-مشكلات شديد روحى و جسمى پس از طلاق-تغيير نخرش به جنس مذكر -

$$
\text { انخشت نما شدن- حمايت اطرافيان }
$$

-افت تحصيلى ڤّ از طلاق-ِيشرفت تحصيلى ڤّ از طلاق به علل كاهش

$$
\text { در خيرى ذهن }
$$

-عدم تناسب اقتصادى فرهنگى و اعتقادى-الكو يذيرى زياد از خانواده و دخالت

$$
\text { آنها-بى تجربخى و سن كم دختر }
$$

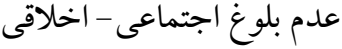

آشفتخى روانى

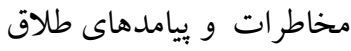

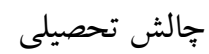

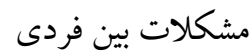


شر كت كننده (ه) "بدرم جِند سال يِيش از مامانم جدا شده بود و ما رو ترك كرده ولى هنوز خيلى دوستش دارم هر وقت زنكک مى زدم بهش، يا او بهم زنخك مى زد شوهرم منو دعوا مى كرد كه جراديخر باهاش ارتباط دارى". نقش شبكه هاى مجازى و ارتباطات خارج از عرف هم بى تاثير نبود. شركت كننده (F) "

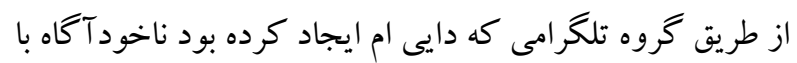
يسره آشنا شدم اول كه يِام ساده داده بودم و ازش زياد خوشم نمى آمد اما بعدش او بيخير بود ول كن نبود". شر كت كننده (9) "قبل از من، دوست دختر داشت حتى بعد از ازدواج هم رابطه با او ادامه مى داد و حتى كاهى اوقات منو به اسم او دختره صدا مى زد، خيلى اذيت مى شدم ". شركت كننده (V)"تو گو شيش ديدم كه به زنان متاهل و دختر غريبه ويام ميده مى گفت حالا با جند تا بيام كه مشكلى يِش نمياد". عدم مسئوليت پذيرى: مسئوليت يذيرى از اركان اساسى يكك زندگى زناشويى است. عدم مسئوليت بذيرى يكى از زوجين سبب تزلزل و اختلال در روابط زوجين مى گردد. برخى از دانش آموزان مطلقه تمايل به تفريحات قبل از تاهل، عدم تمايل به اشتغال مستمر و دايم و نيز عدم تعهد در برداخت مهريه و نفقه در همسرشان را در سوق دادن زندگى آن ها به طلاق و جدايى موثر مى دانستند. مشاركت كننده (r)"شايد باورتون نشه شب عروسى مون تاصبح منو تنها گذاشت و تو زير زمين با پِر دايى هاش قليون كشيد اين كارش تقريبا هر روزه شركت كننده (9)"خيلى رفيق باز بود و اون ها هم برش مى كردن و كاهى به خاطر ترغيب و هم نشينى با اون ها ترياك و مشروب استفاده مى كرد".
نقصان ارتباطى:مشكلات ارتباطى يكى از مسائلى است كه باعث اختلاف و آسيب در روابط زوجين مى شود. دانش آموزان مطلقه به نحوى با اين مشكل مواجه بودند و آنرا در بروز طلاق موثر مى دانستند. ازجمله اين موارد عدم آشنايى مرد با مهارت هاى ارتباطى بود. مشاركت كنند كان اين مساله را با جملاتى ماند پِنهان كارى زياد مرد، لجبازى زياد مرد و تغيير رفتار مرد پِ از عقد و ضرب و شتم بيان كردند و اكثر شر كت كند كان به عدم مهارت همسرشان در ارتباط اشاره كردند.شركت كننده (Y) "حتى جند دفعه تو گوشيش ديدم به زنان غريبه بيام داده كفتم دست بردار ولى مى كفت با جند تا بيام قرار نيست طورى بشه" شر كت كننده 1 "فحاشى زياد مى كرد به خصوص به خانوادم. دست بزن هم داشت ولى كاهى من عصبانى مى شدم و من هم با او

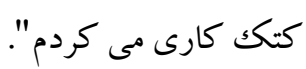

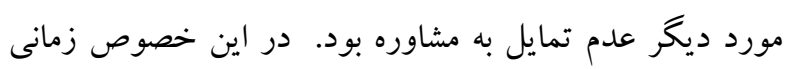

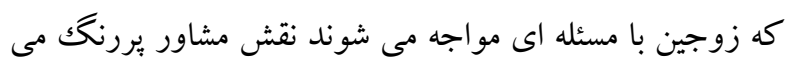
شود. مشار كت كننده (9) "با ضرب و زور خانو اده اش را راضى لئ كرديم بريم مشاور، مشاور در نظرش بود كه صبر كنيم جند ماه و بيشتر آشنا شيم ولى خانواده ها نكذاشتن". شركت كننده (1)" شوهرم مى گفت مشاوره جيه؟ خودم مشاورم. وحاضر نبود

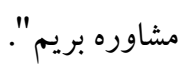
اعمال محدوديت هاى ارتباطى مقوله فرعى ديخرى در اين زمينه بود. اعمال محدوديت هاى ارتباطى كه شامل ممانعت از ارتباط با خانواده يدرى و مخفى كارى از خانواده يدرى كه بيشتر از طرف مرد وضع مى گردد، مى تواند روابط زوجين را مخدوش سازد. 
شر كت كننده (9) "از روز اول از قيافه اش خوشم نمى اومد ولى اقوام خيلى ازش تعريف كردن، اين بد اومدن ازش تا روزى كه

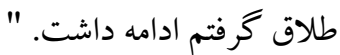

عدم بلوغ اجتماعى- اخلاقى:بلوغ اجتماعى و اخلاقى يكى ديخر از مقولات اصلى در اين تحقيق است.

وابستخى فكرى و اقتصادى شديد به خانواده بدرى زمينه ساز اختلاف و كاهى جدايى در زوجين است. شركت كننده (F)" از نظر مالى هيج استقلالى نداشت و كاملا دستش تو جيب بدرش بود و او خرجى ما رو مى داد".

شر كت كننده (ه)" مادرش تو زندگى همه كاره بود و يكك خانواده مادر سالار بودند بدون اجازه مادرش هيج كس حتى يدرش هيج كارى نمى كردند همه از مادرش حساب مى بردند." به همان اندازه كه دخالت در زندگى زوجين سبب اختلاف مى شود؛ سكوت نابجاى خانواده هم مى تواند به مشكلات يِش آمده بين زوجين دامن بزند. شر كت كننده (Y) "جند دفعه به مادر شوهرم كه خاله ام بود از مشروب خوارى و رفيق بازى بيش از حد بِرش گفتم، ولى او مدام طرفدار پسرش بود و در برابر كارهاى نادرست همسرم

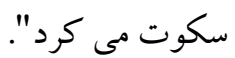

يكى از دلايل نادرست در انتخاب همسر، انتخاب همسر كم سن وسال و عدم بلوغ اجتماعى است. شركت كننده (1) " مى خواستم اخلاق و رفتار زنم رو خودم عوض كنم عمدا زن

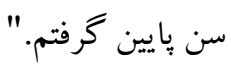
شركت كننده شماره(1) "در جر و بحث ها به خانو اده ام زياد فحش ميداد و منم مثل او فحش مى دادم و داد مى زدم. من همه
كاهى عدم پايبندى به كسب درآمد و تغيير متوالى در شغل مى تواند زمينه را براى اختلاف زناشويى فراهم كند. شركت كننده (9)" اول خواستگارى گفت بنكاه داره ولى بعدش معلوم شد دروغ مى گه در واقع بيكار بود". شركت كننده (1) "يكك روز بنايى مى رفت و يه ماه تو خونه مى موند و بيكار بود". از جمله دلايل طلاق، عدم برداخت نفقه توسط شوهر است و حتى زمانى كه زن متقاضى طلاق هم بشود، مرد حاضر به جنين كارى با ميل و رغبت نيست و تلاش مى كند تا به هرنحوى خودش را از اين مهريه و نفقه راحت كند. شركت كننده (F)" جون بِدرش رشته حقوق خونده بود با جند ترفند و امضا گرفتن از بابام جقدر از حق و حقوقم را بالا كشيد". شركت كننده (ه)" اين قدر اذيت كرد كه بابام گفت مهريه رو مى بخشم تا راحت شى در واقع قصدش از اذيت كردن همين بود كه ما همه جيز رو ببخشيم". عدم صميمت زناشويى:بين كاهش صميميت زناشويى و طلاق يكك رابطه دو سويه وجود دارد، گاهى عدم صميمت زناشويى زوجين زمينه ساز طلاق مى شود و از طرفى وقتى زوجين به طلاق مى انديشند، صميميت در بين آن ها كمرنگك مى شود. بى علاقكى و نداشتن احساس نسبت به همسر يكى از مسيرهاى هدايت زوجين به سمت دلزدگى است. علاقه و دوست داشتن جيزى نيست كه بشود به اجبار ايجاد كرد و جنين مساله اى در يثزوهش حاضر مشهود بود. شركت كننده (r) "با وجودى كه همسرم پسر خاله ام بود، اما هيج علاقه اى بهش نداشتم، به اصرار مادرم قبول كردم كه عقد كنيم و بعد هم

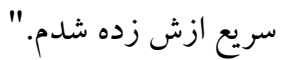


ديدم داره يكى دو تا قرص به زور بهش مى ده، بعدا فهميدم مشكل روانى شديد داشته، تا حدى كه به خاطر اون از سربازى هم معاف شده." - n مخاطرات و بيامدهاى طلاق:مخاطرات و بيامدهاى طلاق در تمام زوجينى كه زندگى شان به طلاق منجرشده ديده مى شود. يكى از بيامدهاى طلاق براى افراد مشكلات جسمى و روحى

با توجه به اينكه اكثر شركت كندكان نوجوان بودند بيشتر از نظر جسمى به هم ريختند و كاهى هم در گير دوره هايى از

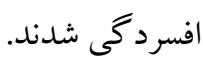
شر كت كننده (9) "بعد از طلاق به قدرى از لحاظ جسمى و روحى بهم ريخته بودم كه سردردهاى بد و حالت تهوع شديد داشتم تقريبا هر هفته يه دفعه بايد سرم مى زدم" شركت كننده (9) "تا جند وقت پِس از طلاق معده درد شديد داشتم و ميخرن عصبى گُفته بودم تا جند وقت آرام بخش مى خوردم." از بيامدهاى ديخر تغيير نخرش نسبت به جنس مذكر و انگشت نما شدن است. شر كت كننده (9) "نظرم به مردها خيلى عوض شده و انغار تنها مرد خوب دنيا بابامه." شركت كننده (•) "از نظر من تمام مردها بدن، اون قدر از دست همسرم زجر كشيدم كه حالا حالا ها ديخر ازدواج نمى كنم اكه هم بخوام ازدواج كنم حسابى تحقيق مى كنم و مشاوره

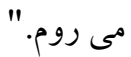
مشاركت كننده (11)" انگار هم دنيا دارن نغام مى كنن و منو به هم نشون مى دن" مشار كت كننده (F)"بخاطر نظر بجهه هاى مدرسه تقريبا جند ماه بعد از طلاقم ديخر مدرسه نرفتم و فقط براى امتحان مى رفتم. آخه تو مدرسه منو نشون مى دادن.
ى تقصيرها رو به گردن او نمى ندازم، آخه منم مهارت همسر دارى بلد نبودم. الان مى فهمم مى تونستم روش تاثير بخذارم". آشفتكى روانى:يكى ديخر از مقولات اصلى در اين تحقيق

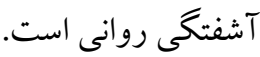
در برخى از زن و مردهاى مطلقه، عدم تعادل روانى و خلقى در يكى از زوجين در بى ثباتى زندكى آن ها موثر بوده است. اين نابسامانى ها در رابطه با زندگى برخى از دانش آموزان مطلقه

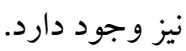
مشار كت كننده (9) " جند روز بعد از عقد كلا اخلاق همسرم عوض شد. بهانه گيرى مى كرد. گاهى مى گفت تو را دوست ندارم، كاهى جند روز جند روز نمى امد و بعضى روزها مى كفت دوستت دارم." در برخى موارد اين آشفتخى روانى به كتكك كارى و دعوا هم مى كشد. مشار كت كننده (•1) "روز دوم يا سوم پس از عقد بود و من تو خونه عى باباش با او تنها بودم كه بحثمون شد جاقو رو به سمتم يرت كرد و كفت: مى كشمت. وقتى ديد بهم نخورد، كلدون كل طبيعى رو طرفم برت كرد كه نزديك بود به سرم بخوره. "شركت كننده (V) "زياد منو مى زد اونم بيخودى، بابام وقتى فهميد گفت اين ديونه است و طلاقت رو مى گيرم." برخى از دختران و بسرانى كه قبل از ازدواج، داروهاى اعصاب و روان مصرف مى كردند؛ بعد از ازدواج اين موضوع را از همسرشان كتمان نمودند و معتقد بودند در صورت ابراز آن ممكن است ازدواج انجام نشود. شر كت كننده F"يكك بار كه خيلى عصبانى شد و كتك كارى كرد، مامانش كه طبقه بالا بود، سرو صدا و فحش هايش را شنيد، صداش كرد كه بره بالا بيشش، يه بار بشت سرش رفتم 
مشكلات بين فردى: همان گونه كه در زندگى برخى از افراد مطلقه، ناهمگونى در رابطه با شرايط، اقتصادى، فرهنگى و اعتقادى مشاهده مى كنيم در رابطه برخى از دانش آموزان مطلقه نيز اين ناهمكونى ها به جشم مى خورد.شركت كننده (F) و (•)" مدام وضع اقتصادى بهترشان را به رخ من و خانواده ام

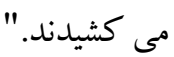
شر كت كننده (ه)" پِ از عقد متوجه تفاوت زياد تو مسائل اعتقادى شدم. اون اصلا نماز نمى خوند و به راحتى با دختراى ديخر جت مى كردو ما خانوادگى اين جورى نبوديم". -الكو يذيرى زياد از خانواده و دخالت آن ها هم در اين مورد بى تاثير نبود. شركت كننده (ه) "هر اتفاقى مى افتاد رو به خانواده اش مى كفت و مطيع كامل مامانش بود و بدون نظر اون آب نمى خورد خيلى مادر سالار بود." در ازدواج در سنين بايين بى تجربكى و عدم مهارت در ارتباط با همسر به طور وضوح به جشم مى خورد كه اين خود زمينه ساز يكك زندگى متزلزل مى باشد. سن بايين دختر نيز به دليل كنار نيامدن با مسائل بلوغ و بحران هويت در آسيب رساندن به پايه هاى زندگى مشترك بى تاثير نيست. شركت كننده (1)" قبول دارم كه سن خودم هم كم بود و تجربه نداشتم، آخه زود

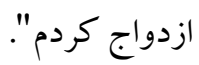

شر كت كننده (F)" من نمى دونم جرا، خانو اده ام مرا در اين سن كم عروس كردند.من جز درس هيج تجربه اى از زندكى نديدم

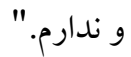
براى درك بهتر خروجى، از مدل مفهومى يُزوهش استفاده شد كه در ادامه آمده است(شكل (1).
دختران و زنان آسيب ديده از طلاق جهت ترميم دوباره زندكى و كنار آمدن با شرايط نامناسب پِ از جدايى نياز به حمايت و هشتيبانى از اطرافيان دارند اين حمايت ها به جند صورت ديده مى شود. الف) حمايت خانواده ب) حمايت دوستان. شركت كننده شماره (9) "خداييش خانواده هيج وقت تنهام نخذاشته و هميشه يشتم بودند حتى مامانم تو كلاس ورزش منو ثبت نام كرده كه هم ازحالت افسردگى و گُشه نشينى در بيام و

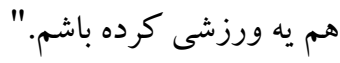
شركت كننده (•.)" بابا هم با وجودى كه وضع ماليش خيلى خوب نيست گفت بابا نخران نباش اكه تا هميشه هم تو خونه ام بمونى هواتو دارم و بشتت هستم." جالش هاى تحصيلى:برخى دانش آموزان مطلقه بعد از طلاق دجار افت تحصيلى و برخى ديخر نه تنها افت تحصيلى، بلكه بدنبال بيشرفت و بهبود شرايط تحصيلى هستند. يكى از بيامدهاى طلاق، افت تحصيلى است. جه زمانى كه والدين دانش آموز طلاق بخيرند و جه زمانى كه خود دنش آموز در گير طلاق شود.شركت كننده (9) "زمانى كه تو گيرو دار طلاق بودم، سر كلاس و موقع درس خواندن، حواسم برت بود. تو كلاس درس فقط جسمم حضور داشت و ذهنم جاى ديگه بود. درسم هم خيلى ضعيف شده بود." كاهى بعد از طلاق و يا در حين فرايند طلاق، دانش آموز از نظر فكرى آسوده مى شود و بهتر مى تو اند تمركز كند. شركت كننده (ه) "جون از دستش راحت شده بودم و از درگيرى ها و كتك كارى ها ديخر خبرى نبود، ذهنم آرومتر و

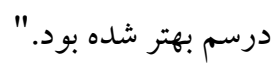




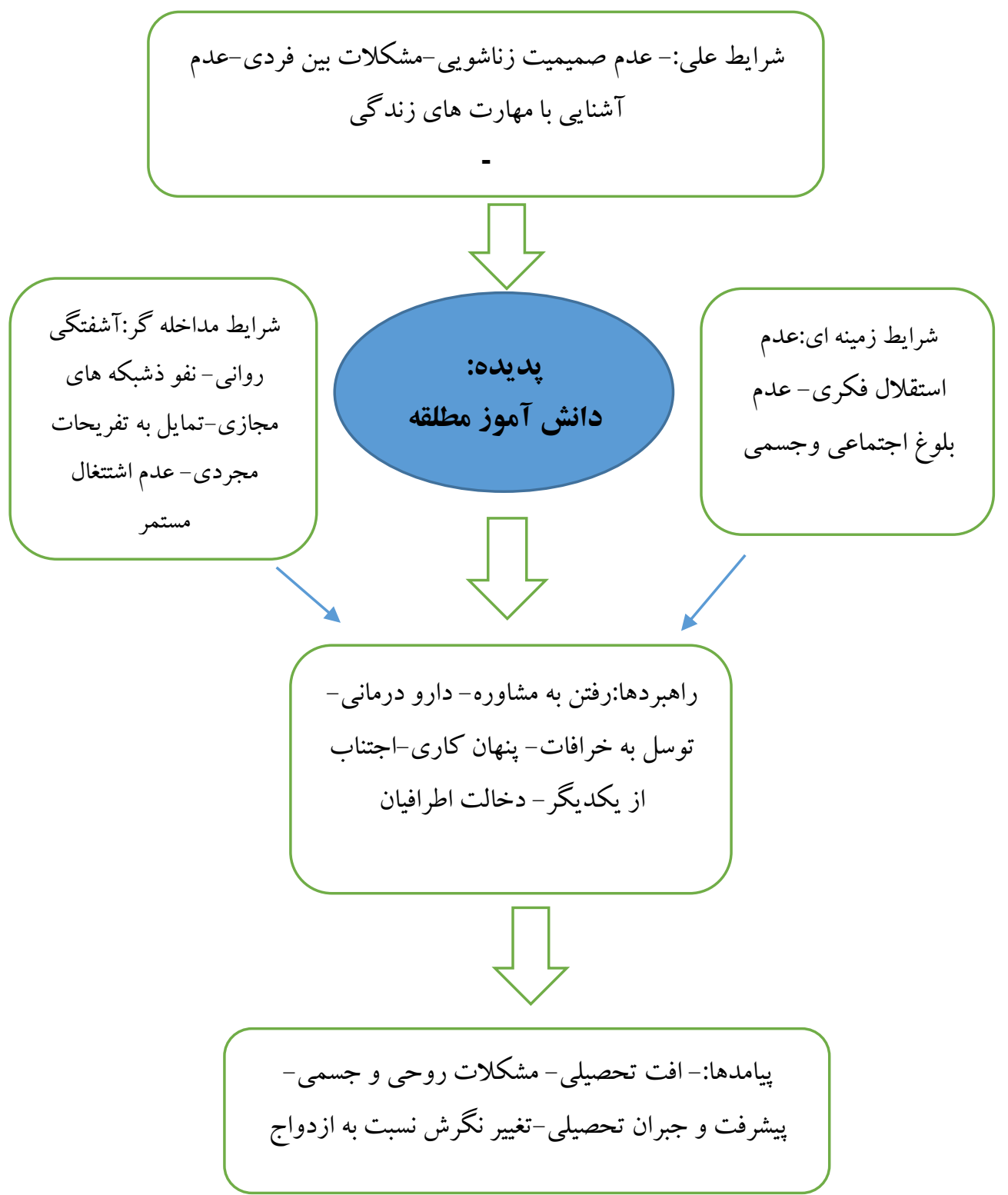

كمتر از هجده سال دارد بايد اين زندگى و ادامه تحصيل را بحث و نتيجه كيرى مديريت كند. تاكنون بُزوهشهاى بسيارى در مورد تاثير طلاق يزّوهش حاضر با هدف بررسى علل و يِيامدهاى ازدواج والدين بر فرزندان انجام گرفته است. ولى مطالعات اندكى در زودهنگام و وقوع كودك همسرى در دانش آموزان دختر استان خصوص طلاق دانش آموزى در داخل انجام شده است. ازدواج يزد انجام شد. همان طور كه يافته ها نيز نشان داد اين نوع زودهنكام هر دو زن و شوهر را تحت تاثير قرار مى دهد. اما ازدواج آسيب هاى بسيارى را بدنبال دارد. بارزترين و مخرب دختران بيشتر از يسران در معرض آسيب اين نوع ازدواج ترين آسيب در اين نوع ازدواج، طلاق است. دانش آموزى كه 
حاضر از معناى طلاق بدست آمد با معناى طلاق در يزوهش

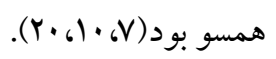

جيزى كه مى تواند معناى ازدواج و طلاق را براى افراد تغيير دهد خانواده و فرهنگك است(ب/(9)). دختر و بسرى كه معناى زندگى متاهلى را درك نكرده باشند وقتى وارد زندگى متاهلى مى شوند ممكن است برداشت هاى شخصى آن ها متفاوت از آن جيزى باشد كه انتظار آنرا داشته اند و اين خود باعث

$$
\text { دلزدگى مى گردد. }
$$

از جمله موارد مشهود كه پِ از ازدواج در تزلزل و شكست ازدواج موثر بود، بى مسئوليت همسر، دخالت هاى اطرافيان، عدم استقلا فكرى و اقتصادى، كاهى ارتباطات خارج ار جارجوب يا خشونت و ضرب وشتم همسر است. اين نتايج با يُزوهش هاى همسو است كه در آن به عوامل فوق اشاره

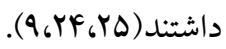

دانش آموزان مطلقه جهت بيشخيرى از طلاق از راهبردهاى جشم يوشى كردن از خطاهاى همسر و مخفى كردن مشكلات، در خواست وساطت از ديخران و كاهى مشاوره استفاده كردند. در اين راستا اين يزوهش با نتايج جند يُوهش ديخر كه در آن معتقدند زوجين از راهبرد مشاوره جهت كاهش اختلافات زندگ泟) در رابطه با تاثير طلاق بر شرايط تحصيلى دانش آموزان مطلقه با جواب هاى متنوع و كاهى متضاد روبرو شديم. برخى بدليل آرام شدن ذهن و روان خود و يرهيز از تنش هايى كه در زندگى متاهلى با آن درگير بودند بيشرفت تحصيلى را پِ از طلاق

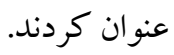

هستند(·r). همان گونه كه مدل بارادايمى نشان داد بيامد اصلى ازدواج زودهنكام، طلاق است. و علت آن هم عدم صميميت زناشويى، مشكلات بين فردى، سن پايين دختر و عدم اشنايى زوجين با مهارت هاى ارتباطى بود. صميميت زناشويى يكى از اركان اصلى زندگى متاهلى است(·r/، (Y). در ازدواج سن بايين شكل گيرى مهارت هاى ارتباطى و اجتماعى دير انجام مى شود و بدنبال آن صميميت در زوجين كاهش مى يابد. زمانى كه صميميت زناشويى و مهارت هاى ارتباطى دجار تزلزل گردد، احتمال طلاق افزايش مى بابد. اين يافته با نتايج مطالعه همسو مى باشد. مهارت هاى ارتباطى بيلى به سوى صميميت زناشويى است (rT، (T، + (). معناى طلاق دانش آموزى در نگاه مشاركت كند كان سوالى بود كه در يى پاسخ آن بوديم. در خارجوب برساخت كرايانه مى توان گفت دانش آموز مطلقه با توجه به وضعيت زندكى زناشويى و موقعيتى كه در آن قرار گرفته است. بديده اجتماعى طلاق و علل و ييامدهاى آنرا درك و تفسير مى كند. براساس اين نظريه تعريف و نوع نگاه فرد به زندگى مهم است. نه زندكى آن ها به صورتى كه در ظاهر ديده مى شود.از نخاه دانش آموزان مطلقه، طلاق يعنى احساس رهايى و آزادى، برجسب نامناسب خوردن و نغرانى از آينده بود. گرجهه معناى طلاق در حقيقت جدا شدن و گسستن ويوند زناشويى است، ولى براى دانش آموزانى كه سابقه زندگى متاهلى را داشتند؛ متفاوت است. طلاق مى تواند درك و معناى زندگى را براى افراد تغيير دهد و آرزوها و نقشه هايى كه دختران براى زندگى آينده خود ترسيم مى كند گاهى با ازدواج فرو مى باشد.آنجه در تحقيق 
هيج زمانى نمى توان جلوى ازدواج زودهنگام را گرفت ولى مى توان اكاهى رادر افراد افزايش داد تا ازدواج با كمترين خطر شروع و ادامه بيدا كند. اميد است خانو اده ها با در نظر گرفتن آفت هاى ازدواج زودهنگام بدنبال تدبيرى براى ازدواج آكاهانه و بهنگام فرزندان شان باشند.

از جمله محدوديت هاى يزوهش حاضر در حوزه روش شناختى دسترسى سخت به دانش آموزانى بود كه عليرغم ازدواج زودهنگًام، طلاق نيز گُرفته باشند. هم جِنين عدم همكارى خانو اده ها باعث مى شد براى ييدا كردن نمونه، يزوهش، هفته ها

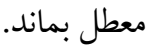
ييشنهاد مى شود ابتدا تجارب زيسته افرادى كه ازدواج زودهنگام دارند شناسايى شود و سبس آموزش مهارت هاى ارتباطى به دانش آموزان دختر و پِر متوسطه دوم با استفاده از مشاوران مدارس در قالب مهارت هاى زندگى ارايه گُدد. هم جنين الزام به مشاوره قبل از ازدواج و شركت در كلاس هاى مهارتهاى همسردارى توسط آموزش و بِرورش در دستور كار

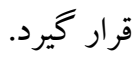

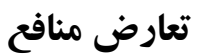
هيج گونه تعارض منافعى بين نويسند كان مقاله نيست.

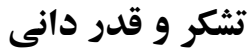
اين بُزوهش زير نظر مديريت كل محترم آموزش و يرورش استان يزد، جناب آقاى موحدى فرد انجام شد. نويسندكان، كمال تشكر و قدردانى خود را از آن مديريت محترم و همه مديران و معلمان محترم مدارس و دانش آموزانى كه ما را در انجام اين تحقيق يارى نمودند را اعلام مى دارند.
برخى ديخر تفاوتى در اين زمينه نسبت به قبل ذكر نكردند. هم جنين در مواردى مشغوليت هاى ذهنى و ترس از آينده مبهم، دانش آموز را به سمت افت تحصيلى پس از طلاق سوق داد. اين يُزوهش با يُزوهش زارعى وهمكاران كه در آن طلاق هم مى تواند به افت تحصيلى و هم ييشرفت تحصيلى منجر شود همسو است.كاهى طلاق زمينه ساز شكل گيرى برخى اختلات مانند وسواس در فرد مى شود و در زمان هايى ديخر مى تواند حتى به جدايى والدين هم ختم گردد(YV).

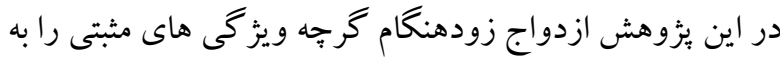
دنبال دارد و مى تواند علاوه بر استقلال فرزندان دغدغه هاى والدين را كاهش دهد، گاهى سبب افزايش بيشرفت تحصيلى شده و زمينه تعالى فرد را فراهم كند. ولى از سويى ديخر ازدواج زودهنگام يا كودكى همسرى جنبه هاى منفى از جمله افت تحصيلى مشكلات خلقى، ناساز گارى، باردارى زودهنكام و خشونت خانكى شود. آنجه در اين بُزوهش مشهود بود ضعف هاى ارتباطى به عنوان يكى از عواملى كه زمينه تعارضات زناشويى در دانش آموزان مطلقه را دامن مى زند است. خانواده ها مى بايست علاوه بر توجه به جنبه هاى تحصيلى فررزندان زمينه ازدواج اكاهانه را براى فرزندان خود فراهم كنند. جه بسا طلاق فرزندان بتواند باعث سردى روابط والدين و گاهى

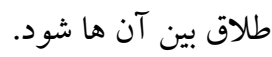
در اين مورد والدين همديخر را متهم به سهل انگارى و سستى مى كنند كه همين باعث اختلاف والدين در آينده مى شود. آموزش و يرورش مىبايست در مقطع متوسطه تدابيرى جهت آموزش مهارت هاى ارتباطى فراهم آورد. 


\section{References}

1- Asghari Sh. Early Marriage in Iran: A Pragmatic Approach, Journal of Human Rights Practice.2019; 11(3):569-88.

2- Montazeri S, Gharache M, Mohammadi N, Alagheband J, Eftekhar H. Determinants of Early Marriage from Married Girls' Perspectives in Iranian Setting: A Qualitative Study. Journal of Environmental and Public Health . 2016;8: 8615929.

3-Valadkhani M, Mahmoudpour A, Farahbakhsh K, Salimi H. The Effects of Partner-Selection Patterns, Marriage Age, and Age Differences between Spouses on Marital Quality of Married Women in Tehran.2016;7(25):173-90.[Persian]

4-Yuksel K,Ilknur. Early Marriage. Journal of Family Issues.2014;35. 1707-24.

5-Faryabi Z, Zareei MahmoodAbadi H. Comparative study of marital adaptation, happiness and divorce inclination in traditional and non-traditional marriages.2015;14(3):83-94.[Persian]

6-Otoo-Oyortey N, Pobi S. Early Marriage and poverty:Exploring links and key policy issues, Gender and development.2003;11(2):42-51.

7- Zareei Mahmoodabadi $H$. the effectiveness of retraining attribution styles on dimensions of family functioning in divorce applicant couples. Journal of Family Counseling and Psychotherapy.2014;4(3):367-87.[Persian]

8-Kalamar A, Lee-Rife S, Hindin, M. Interventions to Prevent Child Marriage Amongst Young People in Low- and Middle-Income Countries: A Systematic Review of the Published and Gray Literature. Journal of Adolescent Health.2016;59: 16-21

9- Zareei Mahmoodabadi H, Zarei F. The Effect of Divorce Counseling based on Gottman's Approach on the Self-Efficacy in Divorce Management of Couples Applying for Divorce. SBRH. 2018;2 (2):219-27

10-UNICEF. "Child marriage fact sheet; Child and forced marriage", early marriage: A harmful traditional practice, New York: United Nations.2005:477-89.

11-Sabbe A. Determinants of child and forced marriage in Morocco: stakeholder perspectives on health policies and human rights. BMC International Health and Human Rights.2013;13(43):1-12. 
12-Avani M, Zareei mahmoodabadi H. Investigation on the Reasons and Backgrounds of Women's Extramarital Relations from Men's Perspective: A Grounded Theory. Journal of Family Counseling and Psychotherapy.2020,10(1):125-50.[Persian]

13-Ministry of Interior National Organization for Civil Registration of Islamic Republic of Iran. 2020,Available from: https://www.isna.ir/news/1400043122265/

14-Cherri Z, Gil Cuesta J, Rodriguez-Llanes JM, Guha-Sapir D.” Early marriage and barriers to contraception among Syrian refugee women in Lebanon: a qualitative study International journal of environmental research and public health".2017; 14(8):836-42.

15-Heidari H, Kimiaei SA, Khoyinejad Gh, Mashhadi A. Discovering the Factors Affecting Divorce in Early Marriages: A Systematic Qualitative Study. J Res Behav Sci. 2019; 17(2): 314-23. [Persian]

16-Meghdadi MM, Javadpour M. Impact of Early Marriage on Children's Sexual Health and Mechanisms of Deal with It. Iran J Med Law. 2017; 11(40): 31-60. [Persian]

17-Javadian S, Shomali Ahmadabadi E, Torkashvand moradabadi M., Abedi, M. The Context and Consequences of Early Marriage of 13-16 Years Old Girls in Ardakan. Journal of Iranian Social Studies.2019; 13(4): 31-54.

18-Eftekharzadeh Z. Lived Experiences of Female Victims of Child Marriage.social worke research.2015;2(3):108-56.[Persian]

19-Biaggi C, Mbaleka S. Grounded Theory: A Practical Overview of the Glaserian SchoolJPAIR Multidisciplinary Research.2018; 32(1):1.

20-Zareei Mahmoodabadi H. Examination of attachment styles and personality factors as predictors of divorce in normal and divorce applicant couples in Yazd, Iran. Journal of Family Counseling and Psychotherapy.2013;2(4):554-72

21-Zareei Mahmoodabadi, H. The Effectiveness of Positive Psychology's Training on Marital Intimacy and Life Expectancy in Women. J Tolooebehdasht Sci.2017; 16(2):98-109.[Persian]

22-Seyfizadeh Arany H, Zareei mahmoodabadi H, Bakhshayesh A. The Reletionship Between Early Maladaptive Schemas and Marital Adjustment with Mediation Fear of Intimacy in Married People. Journal of Family Research.2020;5(4):467-86.[Persian] 
23-Pourmovahed Z, Ardekani SMY, Mahmoodabad, SSM, Mahmoodabadi HZ. Implementation of the McMaster Model in Family Therapy: Effects on Family Function in Married Couples. Iranian Journal of Psychiatry.2021;16(1):60-7.

24-Mahmoodabadi HZ, Bahrami F, Ahmadi A, Etemadi O, Zadeh MSF. The effectiveness of retraining attribution styles (cognitive therapy) on dimensions of family functioning in divorce applicant couples. International Journal of Psychological Studies. 2012;4(2):257-63.

25-Abebe YM. Lived Experiences of Divorced Women in Rural Ethiopia. A Special Focus in Hulet Ejju Enessie Woreda: Addis Zemen Kebele. International Journal of PoliticalScience and Development.2015;3(6): 268-81.

26-Pourmovahed Z, Mazloomy Mahmoodabad SS, Zareei Mahmoodabadi H, Tavangar H, Yassini Ardekani SM, Vaezi AA. Deficiency of Self-Efficacy in Problem-Solving as a Contributory Factor in Family Instability: A Qualitative Study. Iran J Psychiatry. 2018;13(1):32-9.

27-Zareei Mahmoodabadi H, Nasirian M, Sardadvar N. Effectiveness of Psycho Educational Intervention on Improving Symptoms of Patients with Obsessive Compulsive Disorder and General Family Functioning of Companions. Iranian Red Crescent medical journal.2018; 20(2).

28-Bernardi F ,Martinez-Pastor JI.(2011).Divorce risk factors and their variation over time in Spain. Demographic Research.2011;24:771-800. 